DOI 10.26886/2520-7474.3(41)2020.4

UDC 378.14:3

\title{
PEDAGOGICAL PRINCIPLES OF TRAINING BACHELORS IN CYBERSECURITY IN AN EDUCATIONAL-DIGITAL ENVIRONMENT
}

\begin{abstract}
A. Samoylenko, PhD, Associate Professor
https://orcid.org/0000-0002-6374-4168

e-mail: samoylenko_aleksey@outlook.com

Educational and Scientific Institute of Information Security of the Security Service of Ukraine, Kiev, Ukraine
\end{abstract}

The article presents pedagogical principles of preparation of bachelors in cybersecurity in the conditions of educational and digital environment. The pedagogical principles such as purposefulness, scientific character, accessibility, systematicity and consistency, accessibility, consciousness, thoroughness, clarity, interactivity, awareness and effectiveness of learning results, humanization, continuity are characterized. Requirements for the use of pedagogical principles are outlined.

Keywords: pedagogical principles, cybersecurity, training, cybersecurity bachelors.

Кандидат педагогічних наук, доцент, Самойленко О. О., Дослідження стану використання мережі Інтернет в процесі профресійної підготовки бакалаврів з кібербезпеки / Навчальнонауковий інститут інформаційної безпеки Служби Безпеки України, м. Київ, Україна

У статті представлено педагогічні принципи підготовки бакалаврів з кібербезпеки в умовах освітньо-цифрового середовища. Охарактеризовано такі педагогічні принципи, як цілеспрямованості, науковості, доступності, систематичності i послідовності, 
доступності, свідомості, грунтовності, наочності, інтерактивності, усвідомленості i diєвості результатів навчання, гуманізації, безперервності. Окреслено вимоги щодо використання педагогічних принципів.

Ключові слова: педагогічні принципи, кібербезпека, профресійна підготовка, бакалаври з кібербезпеки.

Вступ. Як визначається у Концепції педагогічної освіти України, бакалавр - це освітньо-кваліфікаційний рівень педагогічного працівника, який оволодів фундаментальними, соціальногуманітарними, психолого-педагогічними і фраховими знаннями. Профресійна підготовка бакалавра 3 кібербезпеки - це цілеспрямований, системний і послідовний процес підпорядковане певній системі принципів, дотримання яких забезпечує його ефективність. Принципи в педагогіці - це основні положення, що визначають зміст, організаційні фрорми та методи навчальної роботи вищої школи, а отже, для підготовки бакалавра з кібербезпеки педагогічні принципи потребують більш детального аналізу та педагогічної характеристики.

Мета: Охарактеризувати та проаналізувати педагогічні принципи підготовки бакалаврів з кібербезпеки в умовах освітньо-цифрового середовища

Виклад основного матеріалу. Принцип підготовки бакалавра 3 кібербезпеки, відображаючи якийсь один істотний аспект процесу навчання, $\epsilon$ основою для формулювання правил профресійної підготовки, які залежать від принципу навчання, конкретизують його, підпорядковуються йому і сприяють його реалізації. Вони функціонують як практичні вказівки, якими користуються в конкретній навчальній ситуації. До педагогічних принципів підготовки бакалавра 3 
кібербезпеки віднесено наступні: цілеспрямованості, науковості, доступності, систематичності і послідовності, доступності, свідомості, ґрунтовності, наочності, інтерактивності, усвідомленості і дієвості результатів навчання, гуманізації, безперервності.

Під принципом прийнято розуміти систему вихідних, основних вимог до навчання, виконання яких забезпечує ефективне здійснення завдань учіння і розвитку особистості (Чайка, Основи дидактики: навч. посіб., 2011). Проаналізуємо кожен з окреслених принципів.

Принцип цілеспрямованості навчання. Застосування цього принципу вимагає знання основної мети освіти, завдань навчання, уміння в конкретній ситуації ставити оптимальні освітні завдання, розвитку і виховання, враховуючи реальні навчальні можливості здобувачів освіти конкретного спрямування (Чайка, Основи дидактики : навч. посіб., 2011).

Згідно з освітньою програмою, основними освітніми завданнями є: оволодіння бакалаврами з кібербезпеки системою наукових знань, практичних умінь і навичок, специфрічних для кожної навчальної дисципліни; розвиток розумових здібностей і пам'яті, волі, потреб, інтересів, здібностей; фрормування наукового світогляду, моральної, трудової, естетичної та мережевої культури.

Плануючи зміст, методи і фрорми навчання, потрібно забезпечити усвідомлення бакалаврами з кібербезпеки всього комплексу завдань кожного елементу освітньо-цифрового середовища. Такі завдання мають відображати основні ланки процесу засвоєння знань: від сприймання навчальної інформації до використання знань на практиці.

Принцип науковості в контексті підготовки бакалаврів 3 кібербезпеки в умовах освітньо-цифрового середовища передбачає розкриття причиново-наслідкових зв'язків явищ, процесів, подій, 
включення в засоби навчання науково перевірених знань, які відповідають сучасному рівню розвитку науки.

Він реалізується в змісті навчального матеріалу, зафіксованому в навчальних програмах і підручниках (Чайка, Основи дидактики : навч. посіб., 2011). Із принципу науковості випливають такі вимоги до підготовки бакалаврів з кібербезпеки в умовах освітньо-цифрового середовища:

- ознайомлювати з історією винаходів в області кібербезпеки;

- об'єктивно висвітлювати наукові факти, поняття, теорії захисту кіберпростору;

- ознайомлювати 3 новими професійними досягненнями майбутніх бакалаврів з кібербезпеки;

- показувати перспективи розвитку науки в віртуальному сучасному світі;

- озброювати бакалаврів з кібербезпеки методами науки;

- коригувати знання, які отримані самостійно за допомогою засобів масової інформації;

- пояснювати значення теорії для практики в умовах освітньоцифрового середовища;

- розкривати внутрішні зв'язки і відношення, причиново-наслідкові зв'язки в процесах і явищах кіберпростору.

Принцип доступності. За цим принципом методи і засоби навчання слід добирати відповідно до рівня розумового, морального і фізичного розвитку, щоб інтелектуально та фізично не перевантажити їх (Чайка, Основи дидактики: навч. посіб., 2011). Проте це не означає, що зміст навчального матеріалу в умовах освітньо-цифрового середовища має бути спрощеним, елементарним. Навчальні завдання повинні перевищувати рівень пізнавальних можливостей бакалаврів 3 
кібербезпеки, спонукати їх до напруження пізнавальних зусиль, долання посильних труднощів.

Принцип систематичності і послідовності вимагає дотримання наступності у вивченні окремих тем і навчальних дисциплін, забезпечення логічних зв'язків між засвоєнням способів дій і знань, між формами і методами навчання та формами і методами контролю (самоконтролю) за навчально-пізнавальною діяльністю здобувачів освіти, передбачає безперервний перехід від нижчого до вищого підготовки. За такої умови майбутні бакалаври 3 кібербезпеки засвоюють більший обсяг навчального матеріалу в умовах освітньоцифрового середовища із значною економією часу.

Цей принцип реалізується в різноманітних формах планування, до яких належить порядок вивчення окремих питань теми, послідовність теоретичних і лабораторних робіт (Чайка, Основи дидактики: навч. посіб., 2011).

Вимоги до підготовки бакалаврів 3 кібербезпеки в умовах освітньо-цифрового середовища, що випливають із принципу систематичності і послідовності, такі:

- встановлювати міжпредметні зв'язки і співвідношення між поняттями під час вивчення теми, навчального предмета в умовах освітньо-цифрового середовища;

- використовувати логічні операції аналізу та синтезу під час профресійної підготовки;

- забезпечувати послідовність етапів засвоєння знань бакалаврами з кібербезпеки;

- здійснювати планомірний порядок навчання в умовах освітньоцифрового середовища;

- поступово диференціювати та конкретизувати загальні положення кібербезпеки та ключові аспекти роботи у кіберпросторі; 
- розподіляти навчальний матеріал в умовах освітньо-цифрового середовища на логічно завершені фррагменти, встановлюючи порядок і методику їх опрацювання бакалаврами з кібербезпеки;

- визначати змістові центри кожної теми, виокремлювати основні поняття, ідеї, встановлювати зв'язки між ними, структурувати освітній контент для окресленої категорії;

- розкривати зовнішні та внутрішні зв'язки між теоріями, законами і фрактами, використовувати міждисциплінарні зв'язки;

- визначати місце нового матеріалу в структурі теми чи розділу освітньо-цифррового середовища.

Принцип свідомості передбачає використання логічних операцій і позитивного, відповідального ставлення здобувачів вищої освіти до процесу навчання. Відповідно до вимог навчання буде ефективним тоді, коли майбутні бакалаври з кібербезпеки проявляють пізнавальну активність, є суб'єктами навчальної діяльності в умовах освітньоцифрового середовища (Чайка, Основи дидактики: навч. посіб., 2011).

Із принципу свідомості випливають такі вимоги до підготовки бакалаврів з кібербезпеки в умовах освітньо-цифрового середовища:

- забезпечувати усвідомлення здобувачами вищої освіти цілей i завдань процесу підготовки;

- планувати та організовувати власну навчальну роботу в умовах освітньо-цифрового середовища відповідно до поставлених цілей;

- виявляти інтерес до різних форм занять і видів діяльності в контексті навчального цифрового курсу;

- ставити проблеми і знаходити шляхи їх розв'язання;

- цілеспрямовано докладати зусиль щодо досягнення запланованого результату в умовах освітньо-цифрового середовища. 
Принцип ґрунтовності передбачає точність, доказовість і повноту знань. Ці характеристики знань бакалаври з кібербезпеки забезпечуються тоді, коли навчальний матеріал належно структурований, виокремлено головне, визначено логічні зв'язки між елементами знань (Абашкіна, 1998).

Вимоги, що випливають із принципу ґрунтовності процесу підготовки бакалаврів з кібербезпеки:

- послідовно застосовувати всю дистанційну систему дидактичних принципів, законів і закономірностей підготовки;

- здійснювати засвоєння матеріалу структурованими невеликими частинами;

- виконувати оптимальну кількість навчальних вправ в контексті цифрового дистанційного курсу;

- систематично і безпомилково будувати повторення вивченого матеріалу в умовах освітньо-цифрового середовища;

-.домагатися осмисленого набуття професійних компетентностей та використання їх на практиці;

- здійснювати установку на запам'ятовування знань бакалаврів 3 кібербезпеки в умовах освітньо-цифрового середовища.

Принцип наочності закладає в основу необхідність залучати різні органи відчуття до процесу сприймання та аналізу навчальної інфрормації. Протягом онтогенезу (індивідуального розвитку) послідовно розвиваються три види мислення: наочно-дійове, наочно-образне і абстрактно-теоретичне (понятійне). У процесі навчання всі вони тісно взаємодіють. Понятійне мислення неможливе без наочного (Чайка, Основи дидактики : навч. посіб., 2011).

Принцип наочності висуває до процесу підготовки бакалаврів 3 кібербезпеки такі вимоги: 
- навчати на конкретних цифрових образах, які безпосередньо сприймаються здобувачами вищої освіти;

- спрямовувати сприймання бакалаврів 3 кібербезпеки на найістотніші ознаки та особливості предметів;

- створювати тенденції в пізнавальній діяльності здобувачів вищої освіти в умовах освітньо-цифрового середовища до уявлення реальних предметів, явищ навколишньої дійсності;

- звертати увагу майбутніх бакалаврів 3 кібербезпеки на внутрішню суть зображень,

- від уявлень, конкретних образів в цифровому середовищі підводити здобувачів вищої освіти до осмислення і пізнання внутрішньої сутності явищ;

- забезпечувати оптимальне співвідношення конкретного й абстрактного;

- раціонально поєднувати всі засоби підготовки бакалаври 3 кібербезпеки, забезпечувати розвиток образного мислення у здобувачів вищої освіти.

Принцип інтерактивності. Термін «інтерактивний» походить від англійських слів «inter» - «взаємний» та «асt» - «діяти», і означає «знаходитись у постійному діалозі, бути активним учасником». Відповідно, інтерактивне навчання - це навчання, побудоване на активній взаємодії викладача та здобувачів вищої освіти (Інтерактивні методи навчання, 2020).

Поняття «інтерактивний» походить від англ. «interact» («inter» «взаємний», «асt» - «діяти»). Інтерактивне навчання - це специфічна форма організації пізнавальної діяльності, яка має передбачувану мету - створити комфортні умови навчання, за яких кожен учень відчуває свою успішність, інтелектуальну спроможність (Вербицкий, 1989, с. 16). В своїх дослідженнях М.В.Кларін, розглядаючи проблеми 
інтерактивного навчання, стверджує, що «це спеціальна форма організації пізнавальної діяльності учнів, що включає конкретні цілі, а саме створення комфортних умов навчання, за допомогою яких учень відчуває свою успішність, свою інтелектуальну спроможність, що робить продуктивним сам процес навчання» (1998, стр. 58-59). Ю.М. Фокін, розглядаючи використання інтерактивних методів навчання, дає їм таке трактування: «Інтерактивні методи навчання орієнтовані на більш широку взаємодію учнів не тільки з вчителем, а й один $з$ іншим і на домінування активності учнів в процесі навчання» (Фокин, 2002, стр. 122)

Суть інтерактивного навчання бакалаврів з кібербезпеки полягає у тому, що освітній процес відбувається за умови постійної, активної взаємодії всіх здобувачів вищої освіти в умовах освітньо-цифрового середовища. Це базується на співпраці, взаємо - навчанні: вчитель здобувач вищої освіти, здобувач вищої освіти - здобувач вищої освіти. При цьому вчитель і здобувач вищої освіти - рівноправні, рівнозначні суб'єкти навчання. Інтерактивна взаємодія виключає домінування одного учасника навчального процесу над іншим, однієї думки над іншою. Під час такого спілкування бакалаври з кібербезпеки вчаться бути демократичними, спілкуватися 3 іншими людьми, критично мислити, приймати обґрунтовані рішення.

Принцип усвідомленості і дієвості результатів навчання. Стосовно до вченню значення свідомості і активності вдало висловив С.Л. Занков, давши розширювальне трактування цього принципу в навчанні: «...вирішальне значення має оволодіння теоретичними знаннями, а це значить їх осмислення і засвоєння на понятійному рівні і усвідомлення прикладного значення теоретичних ідей; учні повинні усвідомлювати технологію навчання і володіти прийомами навчальної роботи, тобто технологією по засвоєнню знань.» (Занков, 1999) 
Реалізація цих умов вимагає високої активності і свідомості здобувачів вищої освіти.

Ґрунтується на усвідомленні неможливості універсальних підходів до підготовки бакалаврів з кібербезпеки, які спрацьовують у будь-яких педагогічних ситуаціях. Успішно вирішити педагогічну проблему можна різними поєднаннями форм і методів роботи в умовах освітньоцифрового середовища. Цей принцип відображає демократичність умов роботи сучасної вищої школи, які дають педагогам право вибору на науковій основі оптимальних для них умов, методів, фоорм і прийомів роботи.

Принцип гуманізації бере в основу термін «гуманізм» (лат. humanus - людяний) означає «ставлення до людини як до найвищої цінності, захист права особистості на свободу, щастя, всебічний розвиток і прояв своїх здібностей». Наприкінці 80-х років XX століття науковий термін «гуманність» подається як принцип світогляду, в основі якого лежить переконання в безмежних можливостях особистості та ії здатності до вдосконалення, до вимог власної волі та захисту громадянських прав. На початку 90-х років поняття «гуманність» розуміється як повага до людей і до їхньої гідності, піклування про їхній добробут (Бондарчук, 2009; Пащенко, 2001).

Процес гуманізації підготовки бакалаврів з кібербезпеки тісно пов'язаний з гуманітаризацією національної системи освіти, яка зумовлена не тільки новим її баченням, а також певними аспектами розвитку сучасного світу в цілому, покликана формувати у здобувачів вищої освіти цілісну картину світу, духовність, культуру особистості.

Принцип безперервності освіти бакалаврів 3 кібербезпеки є систематизуючим. Навчальні заклади, працівники освіти та бакалаври 3 кібербезпеки мають чітко уявляти роль і місце освіти в житті людини і 
суспільства. Необхідно подолати орієнтацію на поверхневу «енциклопедичність» змісту, перевантаження інформаційним матеріалом. У змісті освіти повинні знайти відображення проблеми розвитку кіберсуспільства, виробництва, науки, культури у віртуальному просторі. Освіта повинна бути спрямована в майбутнє та забезпечити бакалаврам з кібербезпеки можливість розвитку протягом життя.

Провідною ідеєю, що покладена світовою педагогічною думкою в основу оновлення освіти, є ідея безперервності освіти (Сбруєва, 2016). Головна ідея принципу безперервності підготовки полягає у створенні для кожної людини можливостей отримання і поповнення знань, можливостей розвитку, удосконалення, самореалізації протягом усього життя (Сбруєва, Порівняльна педагогіка: Навчальний посібник, 1999).

Висновки. Таким чином, визначені педагогічні принципи підготовки бакалаврів з кібербезпеки в умовах освітньо-цифрового середовища нададуть можливість якісної освіти в області кібербезпеки. Впровадження окреслених принципів передбачає навчання на основі новітніх досягнень педагогіки, психології, методики, передового педагогічного досвіду, наполегливого впровадження в практику рекомендацій наукової організації педагогічної праці. У зв'язку з зростаючим потоком освітньої інформації головну увагу необхідно приділяти ключовим проблемам професійної підготовки, розкривати бакалаврам з кібербезпеки основні ідеї наукових досягнень, привчати їх стежити за інформацією, заохочувати колективне обговорення науково-технічних і соціальних проблем.

\section{תimepamypa:}

1. Абашкіна, Н. В. (1998). Принципи розвитку профресійної освіти в Німеччині. Київ. 
2. Бондарчук, О. (2009). Особливості реалізації гуманістичноціннісного підходу у післядипломній педагогічній освіті. Післядипломна педагогічна освіта (№ 13), 3-6.

3. Вербицкий, А. А. (1989). Активные методы обучения в высшей школе: контекстный подход. М.

4. Занков, Л. В. (1999). Избранные педагогические труды. 3-е изд., дополн. М., Дом педагогики.

5. Інтерактивні методи навчання. (2020). Отримано 11. 04. 2020 р. 3 https://www.pedrada.com.ua/article/2316-interaktyvni-metody

6. Кларин, М. В. (1998). Инновации в мировой педагогике: обучение на основе исследования, игры и дискуссии. Анализ зарубежного опыта. Рига, Эксперимент.

7. Пащенко, Д. І. (2001). Генезис гуманістичних ідей у педагогіці: монографрія. Київ, Наук. світ.

8. Сбруєва, А. А. (1999). Порівняльна педагогіка: Навчальний посібник. Суми: Редакційно-видавничий відділ СДПУ.

9. Сбруєва, А. А. (2016). Порядок денний ЄС у сфері вищої освіти: пріоритети програми «Освіта та професійна підготовка 2020». Педагогічні науки: теорія, історія, інноваційні технології: науковий журнал (10 (64)), сc. 110-123.

10. Фокин, Ю. Г. (2002). Преподавание и воспитание в высшей школе: методология, цели и содержание, творчество. Москва, Академия.

11. Чайка, В. М. (2011). Основи дидактики: навч. посіб. Київ, Академвидав.

\section{References:}

1. Abashkina, N. V. (1998). Pryntsypy rozvytku profesiinoi osvity $v$ Nimechchyni. Kyiv. 
2. Bondarchuk, O. (2009). Osoblyvosti realizatsii humanistychnotsinnisnoho pidkhodu u pisliadyplomnii pedahohichnii osviti. Pisliadyplomna pedahohichna osvita (№ 13), 3-6.

3. Verbytskyi, A. A. (1989). Aktyvnye metody obuchenyia $v$ vysshei shkole: kontekstnyi podkhod. M.

4. Zankov, L. V. (1999). Yzbrannye pedahohycheskye trudy. 3-e yzd., dopoln. M., Dom pedahohyky.

5. Interaktyvni metody navchannia. (2020). Otrymano 11. 04. 2020 p. z https://www.pedrada.com.ua/article/2316-interaktyvni-metody

6. Klaryn, M. V. (1998). Ynnovatsyy v myrovoi pedahohyke: obuchenye na osnove yssledovanyia, yhry y dyskussyy. Analyz zarubezhnoho opyta. Ryha, Eksperyment.

7. Pashchenko, D. I. (2001). Henezys humanistychnykh idei u pedahohitsi: monohrafiia. Kyiv, Nauk. svit.

8. Sbruieva, A. A. (1999). Porivnialna pedahohika: Navchalnyi posibnyk. Sumy, Redaktsiino-vydavnychyi viddil SDPU.

9. Sbruieva, A. A. (2016). Poriadok dennyi YeS u sferi vyshchoi osvity: priorytety prohramy «Osvita ta profesiina pidhotovka 2020». Pedahohichni nauky: teoriia, istoriia, innovatsiini tekhnolohii: naukovyi zhurnal (10 (64)), ss. $110-123$.

10. Fokyn, Yu. H. (2002). Prepodavanye y vospytanye $v$ vysshei shkole: metodolohyia, tsely y soderzhanye, tvorchestvo. Moskva, Akademyia.

11. Chaika, V. M. (2011). Osnovy dydaktyky: navch. posib. Kyiv, Akademvydav. 